\title{
Trigubos terapijos viename inhaliatoriuje nauda gydant lètinę obstrukcinę plaučių ligą
}

\author{
THE BENEFIT OF SINGLE INHALER TRIPLE THERAPY IN CHRONIC OBSTRUCTIVE \\ PULMONARY DISEASE
}

\author{
GIEDRE் GUREVIČIENĖ \\ LSMU MA Pulmonologijos klinika
}

\begin{abstract}
Santrauka. Lètinei obstrukcinei plaučių ligai (LOPL) būdinga nuolatinė kvėpavimo takų obstrukcija, sąlygojanti nuolatinius kvejpavimo simptomus, kurie intensyvèja ligai progresuojant bei kartojantis paūmejimams. Remiantis Visuotinès obstrukcinès plaučių ligos iniciatyvos (angl. Global Initiative for Obstructive Lung Disease) rekomendacijomis, triguba medikamentinė LOPL terapija ịkvepiamuoju gliukokortikoidu (iGK), ilgo veikimo muskarino receptorių blokatoriumi (IVMB) bei ilgo veikimo $\beta_{2}$-agonistu (IVBA) indikuotina pacientams, kuriems, nepaisant skiriamo gydymo IVBA/IVMB arba IVBA/iGK, išlieka kliniškai reikšmingų simptomų ir kurie turi padidèjusią vidutinių arba sunkių paūmèjimų riziką. Trigubos medikamentinès LOPL terapijos veiksmingumą demonstruoja FULFIL (angl. Once-Daily Triple Therapy for Patients with Chronic Obstructive Pulmonary Disease) ir IMPACT (angl. InforMing the PAthway of COPD Treatment) klinikiniu tyrimų duomenys. Remiantis jais, įrodytas gydymo trijų skirtingų farmakoterapinių grupių (iGK/IVMB/IVBA) ịkvepiamaisiais medikamentais pranašumas lyginant su dviguba terapija (iGK/IVBA, IVBA/IVMB). Flutikazono furoato / umeklidinio / vilanterolio grupejje nustatytas statistiškai patikimai mažesnis vidutinio sunkumo ir sunkių paūmèjimų dažnis, taip pat užfiksuoti geresni plaučių funkcijos rodikliai bei geresnè su sveikata susijusi gyvenimo kokybẻ lyginant su dvigubo medikamentinio gydymo grupèmis. Tuo tarpu jokių saugumo profilio skirtumų nenustatyta. Taigi triguba medikamentinè terapija viename inhaliatoriuje yra perspektyvus LOPL gydymo būdas atrinktiems pacientams.

Reikšminiai žodžiai: lètinè obstrukcinè plaučių liga, triguba terapija, dviguba terapija.

Summary. Chronic obstructive pulmonary disease (COPD) is characterised by persistent obstruction of lung airflow, determinating respiratory symptoms, which increase while disease is progressing and exacerbations are reccuring. According to Global Initiative for Obstructive Lung Disease (GOLD), triple therapy with an inhaled glucocorticoid (iGK), a long-acting $\beta_{2}$-agonist (LABA) and a long-acting muscarinic antagonist (LAMA), should be prescribed for patients who have clinically significant symptoms despite treatment with iGK/LABA or LAMA/LABA and who are at increased risk for moderate or severe exacerbations. Efficacy of triple therapy is demonstrated by FULFIL (Once-Daily Triple Therapy for Patients with Chronic Obstructive Pulmonary Disease) and IMPACT (InforMing the PAthway of COPD Treatment) clinical trials findings. In fluticasone furoate / umeclidinium / vilanterol group a statistically significant reduction in the moderate and severe COPD exacerbations, as well as improvement of lung function and health-related quality of life were observed, comparing with groups of dual therapy. Meanwhile any differences in safety profile were detected. Such triple therapy in single inhaler is promising pathway for COPD treatment in selected patients.
\end{abstract}

Keywords: chronic obstructive pulmonary disease, triple therapy, double therapy.

\section{IVADAS}

Lètinè obstrukcinė plaučių liga (LOPL) - tai progresuojanti kvépavimo takų liga, kurios pagrindinis patogenetinis veiksnys yra lètinis uždegimas, apimantis kvėpavimo takus, plaučių parenchimą bei kraujagysles. Jai būdinga persistuojanti kvėpavimo takų obstrukcija, sąlygojanti nuolatinius kvėpavimo simptomus, kurie dažnejja ligai progresuojant bei kartojantis paūmèjimams [1].

Remiantis Visuotinès obstrukcinės plaučių ligos iniciatyvos (angl. Global Initiative for Obstructive Lung Disease) rekomendacijomis, triguba medikamentinè LOPL terapija ikkvepiamuoju gliukokortikoidu (iGK), ilgo veikimo muskarino receptorių blokatoriumi (IVMB) bei ilgo veikimo $\beta_{2}$-agonistu (IVBA) rekomenduojama, kai, nepaisant skiriamo gydymo IVBA ir IVMB arba IVBA ir iGK, išlieka kliniškai reikšmingų simptomų ir yra vidutinio sunkumo arba sunkių paūmėjimų rizika [2]. Remiantis įvairių klinikinių tyrimų duomenimis, lyginant su dvigubu medikamentiniu LOPL gydymu, triguba medikamentiné LOPL terapija turi teigiamą poveiki plaučių funkcijai, LOPL simptomams ir paūmejjimų rizikai mažinti. Ilgą laiką gydymas trimis vaistais buvo galimas tik naudojant daugiau nei vieną 


\section{Farmakoterapija}

inhaliatorių, o kai kuriuos vaistus įkvepiant ir du kartus per parą. Triguba terapija viename inhaliatoriuje - ilgai laukta naujiena [3]. Inhaliatoriuje talpinamas iGK - flutikazono furoatas, IVMB - umeklidinis ir IVBA - vilanterolis (FF/U/V). Derinị pakanka ịkvèpti vieną kartą per parą. Siekiant ịvertinti šios trigubos terapijos viename inhaliatoriuje poveiki bei saugumo profilį, atlikti du svarbią klinikinę reikšmę turintys tyrimai: FULFIL (angl. Once-Daily Triple Therapy for Patients with Chronic Obstructive Pulmonary Disease), kurio metu lygintas FF/U/V su iGK - budezonido ir IVBA - formoterolio (B/F) deriniu, bei IMPACT (angl. InforMing the PAthway of COPD Treatment), kurio metu lygintas FF/U/V su iGK - flutikazono furoato ir IVBA - vilanterolio (FF/V) bei IVMB - umeklidinio ir IVBA - vilanterolio (U/V) deriniais. Šiame straipsnyje apžvelgiami minètų klinikinių tyrimų duomenys, gauti palyginus trijų vaistų derinio viename inhaliatoriuje veiksmingumą su dviejų vaistų deriniais.

\section{FULFIL KLINIKINIO TYRIMO DUOMENYS}

FULFIL - trečios fazès, atsitiktinių imčių, dvigubai aklas, dvigubai koduotas, paralelinių grupių daugiacentris tyrimas. Šio tyrimo tikslas - įvertinti trigubo vaistų derinio - FF/U/V (100/62,5/25 $\mu \mathrm{g})$ viename inhaliatoriuje, skiriamo vieną kartą per parą, poveikị plaučių funkcijai ir su sveikata susijusiai gyvenimo kokybei, lyginant su dvigubu vaistų deriniu - B/F (400/12 $\mu \mathrm{g})$, skiriamu du kartus per parą.

Pirminè vertinamoji baigtis buvo forsuoto iškvẻpimo tūrio per pirmąją sekundę (angl. Forced Expiratory Volume in 1 Second, $\mathrm{FEV}_{1}$ ) reikšmès ir Šv. Jurgio kvèpavimo klausimyno (angl. the St. George's Respiratory Questionnaire, SGRQ) bendros balų sumos pokytis per 24 gydymo savaites, lyginant su pradiniais duomenimis. Antrinès vertinamosios baigtys: $\mathrm{FEV}_{1}$ atsakas (pokytis nuo pradinės reikšmės $\geq 100 \mathrm{ml}$ ), kliniškai reikšmingas Šv. Jurgio kvėpavimo klausimyno bendros balų sumos pokytis (sumažejimas $\geq 4$ balais nuo pradinès vertės) bei LOPL paūmèjimų dažnis gydymo laikotarpiu.

Tyrime dalyvavo vyresni nei 40 metų pacientai, sergantys išreikšta bronchų obstrukcija: $\mathrm{FEV}_{1}<50$ proc., arba $\geq 50 \mathrm{FEV}_{1}<80$ proc., su išreikštais LOPL simptomais (LOPL vertinimo testo (angl. COPD assesment test, CAT) reikšmė $\geq 10$ balų) ir per praejjusius metus patyrę bent du vidutinio sunkumo arba bent vieną sunkų LOPL paūméjimą. I klinikinị tyrimą ịtraukta 2240 pacientų: 1810 - i numatytųjų gydyti (angl. intent-to-treat, ITT) (FF/U/V, $\mathrm{n}=911 ; \mathrm{B} / \mathrm{F}, \mathrm{n}=899)$, 430 - i i išplèstinę (angl. Extension, EXT) grupę (FF/U/V, $\mathrm{n}=210 ; \mathrm{B} / \mathrm{F}, \mathrm{n}=220$ ). Tyrimą baige 94 proc. pacientų, iš kurių 90 proc. tiriamuosius vaistus vartojo ir tyrimui baigiantis. Priešlaikinis tyrimo nutraukimas dažniausiai buvo sąlygotas paciento apsisprendimo (4 proc.), nepageidaujamų reiškinių (3 proc.) arba nepakankamo gydymo veiksmingumo (3 proc.). Viso tyrimo metu registruoti visi pasireiškę nepageidaujami reiškiniai. Siekiant geriau prognozuoti artėjantị ligos paūmèjimą, naudotas elektroninis dienynas. Paūmèjimo sunkumas vertintas pagal gydymo intensyvumą: lengvas paūmèjimas - gydymui papildomai skirtas trumpo veikimo $\beta_{2}$-agonistas, vidutinio sunkumo paūmèjimas - skirtas gydymas antibiotikais arba sisteminiais gliukokortikoidais, sunkus paūmèjimas - stacionarinis gydymas.

Šio tyrimo rezultatai parodė, kad per visą 24 savaičių gydymo laikotarpị $\mathrm{FEV}_{1}$ pokytis nuo pradinių reikšmių tyrimo pradžioje buvo žymiai didesnis skiriant trigubą LOPL terapiją FF/U/V nei dvigubo medikamentinio gydymo $\mathrm{B} / \mathrm{F}$ grupèje $(\mathrm{p}<0,001)$ (1 pav. A). Vidutinis $\mathrm{FEV}_{1}$ pokytis trigubos terapijos grupèje siekè $142 \mathrm{ml}$, tuo tarpu dvigubos terapijos grupeje buvo $-29 \mathrm{ml}$. Skirtumai tarp šių grupių buvo statistiškai reikšmingi (171 $\mathrm{ml} ; 95$ proc. pasikliautinasis intervalas (PI): 148-194, $\mathrm{p}<0,001)$. Atvejų skaičius, kuomet $\mathrm{FEV}_{1}$ pokytis buvo $\geq 100 \mathrm{ml}$, lyginant su pradine verte, trigubos terapijos grupeje taip pat buvo statistiškai patikimai didesnis (šansų santykis (ŠS) 4,03; 95 proc. PI, 3,27-4,97; $\mathrm{p}<0,001)$. Panašūs rezultatai gauti ir išplèstinejje populiacijoje 52-ą gydymo savaitę (1 pav. B).
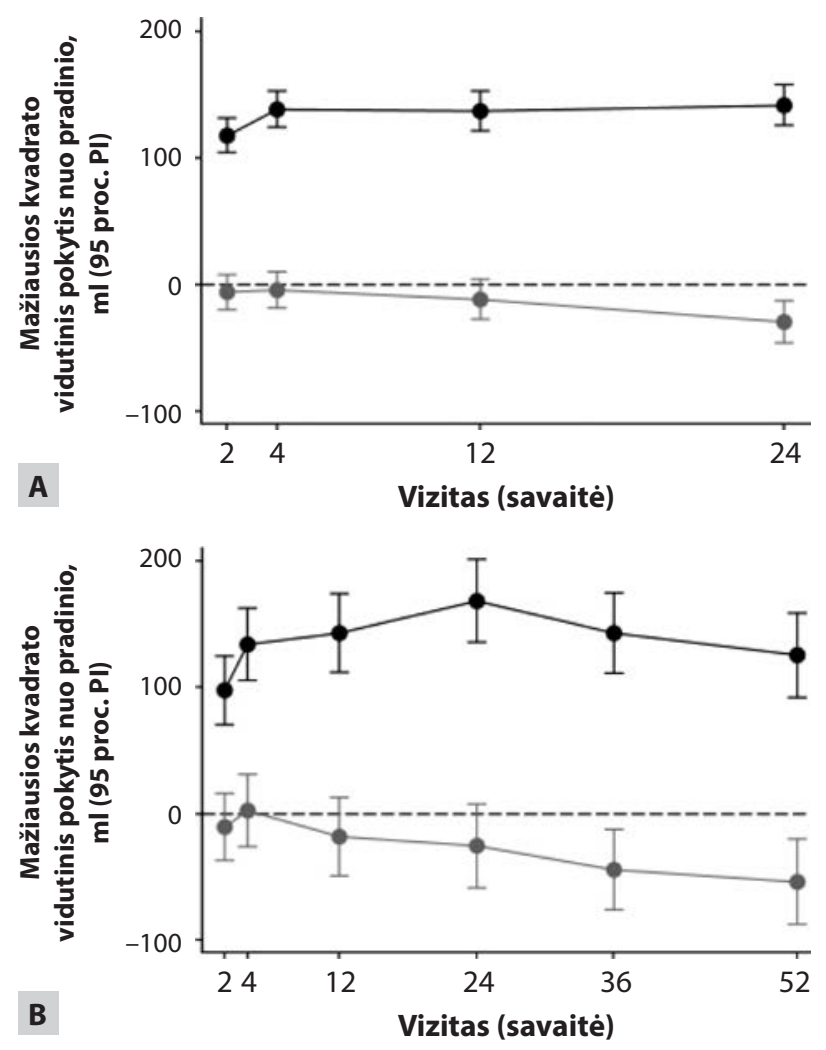

FF/U/V (flutikazono furoatas/umeklidinis/vilanterolis) B/F (budezonidas / formoterolis)

1 pav. Vidutinis $\mathrm{FEV}_{1}$ pokytis lyginant su pradine reikšme: A - 24-tą gydymo savaitę numatytų gydyti tiriamuoju vaistiniu preparatu populiacijoje; B - 52-ą gydymo savaitę išplèstinèje populiacijoje 
Tiriamiesiems 24-tą gydymo savaitę pildant Šv. Jurgio kvėpavimo klausimyną, žymiai didesnis vidutinio bendro balo sumažejimas nustatytas gydytiems FF/U/V ( $-6,6$ balo), nei B/F deriniu $(-4,3$ balo) $(\mathrm{p}<0,001)$. Kliniškai reikšmingas balų pokytis (sumažejimas nuo pradinio lygio $\geq 4$ balais) taip pat buvo didesnis trigubos terapijos grupejje (ŠS 1,41; 95 proc. PI, 1,16-1,70, $\mathrm{p}<0,001)$. Tuo tarpu tyrimo pratęsimo populiacijoje 52-ą gydymo savaitę Šv. Jurgio kvèpavimo klausimyno bendro balo pokytis tarp trigubos ir dvigubos terapijos grupių statistiškai reikšmingai nesiskyrè $(p=0,065)$.

Vidutinis metinis sunkių ir vidutinio sunkumo paūmejjimų dažnis, remiantis numatytos gydyti populiacijos duomenimis, buvo statistiškai patikimai mažesnis trigubos terapijos grupèje, lyginant su dvigubos terapijos grupe ( 35 proc. 95 proc. PI, $14-51, \mathrm{p}<0,002$ ): trigubos terapijos grupejje šių paūmejjimų dažnis buvo 0,22 , dvigubos terapijos grupeje - 0,34 paūmèjimo per metus. Panašūs rezultatai gauti vertinant visus: lengvus, vidutinio sunkumo ir sunkius paūmèjimus (1 lentelè). Trigubos terapijos grupeje taip pat stebėtas mažesnis sunkių LOPL paūmèjimų, gydytų stacionare, skaičius.

Gydymo saugumas tiek trigubos, tiek dvigubos terapijos grupèse buvo panašus. Dažniausiai pasitaikę nepageidaujami reiškiniai, vertinant, 24 ir 52 savaičių gydymo laikotarpi, buvo nazofaringitas ir galvos skausmas. Vertinant 52 savaičių gydymo laikotarpi, LOPL paūmejjimas buvo vienas dažniausių nepageidaujamų reiškinių dvigubos terapijos grupeje (10 proc.), tuo tarpu trigubos terapijos grupeje priskirtas prie rečiau pasitaikiusiųuı (2 proc.) [4].

\section{IMPACT KLINIKINIO TYRIMO DUOMENYS}

IMPACT - trečios fazès, atsitiktinių imčių, dvigubai aklas, paralelinių grupių daugiacentris tyrimas. Šio kli- nikinio tyrimo tikslas - ivertinti trigubos LOPL terapijos FF/U/V (100/62,5/25 $\mu \mathrm{g})$ vieno ịkvejpimo paroje poveiki paūmèjimų dažniui, plaučių funkcijai ir su sveikata susijusiai gyvenimo kokybei bei palyginti su dviguba LOPL terapija FF/V $(100 / 25 \mu \mathrm{g})$ ir U/V $(62,5 / 25 \mu \mathrm{g})$ skiriant derinị kvejpuoti vieną kartą per parą. Tyrime dalyvavo vyresni nei 40 metų asmenys, patiriantys nuolatinius LOPL simptomus (CAT $\geq 10$ balų), pagal LOPL sunkumą atitinkantys sunkią ir labai sunkią ligą $\left(\mathrm{FEV}_{1}<50\right.$ proc.) ir per praejusius metus patyrę bent vieną vidutinio sunkumo arba sunkų paūmèjimą, arba atitinkantys vidutinio sunkumo ligą ( $\mathrm{FEV}_{1} 50-80$ proc.) ir per praejusius metus patyrę bent du vidutinio sunkumo arba vieną sunkų paūmèjimą, nepaisant nuolat skiriamo palaikomojo gydymo. Pirminè vertinamoji baigtis buvo vidutinio sunkumo ir sunkių LOPL paūmèjimų dažnis per 52 gydymo savaites, skiriant trigubą LOPL terapiją - FF/U/V, lyginant su dviguba terapija FF/V ir U/V. Antrinès vertinamosios baigtys apėmė plaučių funkciją, simptomus bei laiką iki pirmo paūmèjimo. Kaip ir pirmo klinikinio tyrimo atveju, naudotas elektroninis dienynas, padèjęs nuspèti ligos paūmèjimus. Viso tyrimo metu registruoti pasireiškę nepageidaujami reiškiniai. Paūmejjimo sunkumas taip pat vertintas pagal gydymo intensyvumą. Sunkiu laikytas paūmẻjimas, pasibaigęs stacionariniu gydymu ar mirtimi.

IMPACT tyrimas truko trejus metus. Per šį laikotarpi itraukti 10355 asmenys (FF/U/V grupeje $n=4151, F F / V$ grupeje $\mathrm{n}=4134, \mathrm{U} / \mathrm{V} \mathrm{n}=2070$ ). Tyrimą baigè 88 proc. pacientų, iš kurių 77 proc. tyrimo pabaigoje vis dar vartojo tiriamuosius vaistus. Priešlaikinis tiriamojo vaisto nutraukimas buvo mažesnis trigubos terapijos grupeje ir siekè 18 proc., tuo tarpu FF/V ir U/V grupèse buvo atitinkamai - 25 ir 27 proc. Nustatytas vidutinio sunkumo ir sunkių LOPL paūmejjimų dažnis 52 savaičių

1 lentelè. Metinis LOPL paūmèjimų dažnis (numatytų gydyti ir išplèstinèje populiacijose)

\begin{tabular}{|c|c|c|c|c|}
\hline & \multicolumn{2}{|c|}{24 sav. (numatytu gydyti populiacija) } & \multicolumn{2}{|c|}{52 sav. (išplèstinè populiacija) } \\
\hline & FF/U/V & $B / F$ & FF/U/V & $B / F$ \\
\hline Tiriamujų skaičius (n) & 907 & 892 & 210 & 219 \\
\hline \multicolumn{5}{|l|}{ Vidutinio sunkumo ir sunkūs paūmèjimai } \\
\hline Vidutinis dažnis & 0,22 & 0,34 & 0,20 & 0,36 \\
\hline Santykis (95 proc. $\mathrm{PI}) ; \mathrm{p}$ reikšmè & \multicolumn{2}{|c|}{$0,65(0,49-0,86) ; 0,002$} & \multicolumn{2}{|c|}{$0,56(0,37-0,85) ; 0,006$} \\
\hline Dažnio sumažinimas, proc. (95 proc. PI) & \multicolumn{2}{|c|}{$35(14-51)$} & \multicolumn{2}{|c|}{$44(15-63)$} \\
\hline \multicolumn{5}{|c|}{ Lengvi, vidutinio sunkumo ir sunkūs paūmèjimai } \\
\hline Vidutinis dažnis & 0,25 & 0,39 & 0,22 & 0,40 \\
\hline Santykis (95 proc. $\mathrm{Pl}$ ); $\mathrm{p}$ reikšmè & \multicolumn{2}{|c|}{$0,65(0,50-0,84) ;<0,001$} & \multicolumn{2}{|c|}{$0,55(0,37-0,81) ; 0,003$} \\
\hline Dažnio sumažinimas, proc. (95 proc. PI) & \multicolumn{2}{|c|}{$35(16-50)$} & \multicolumn{2}{|c|}{$45(19-63)$} \\
\hline
\end{tabular}

Santykiai ir p vertè apskaičiuoti FF/U/V grupę lyginant su B/F grupe. Santrumpos: B - budezonidas; F- formoterolis; FF - flutikazono furoatas; LOPL - lètinė obstrukcinè plaučių liga; $\mathrm{PI}$ - pasikliautinasis intervalas; $\mathrm{U}$ - umeklidinis; $\mathrm{V}$ - vilanterolis. 


\section{Farmakoterapija}

gydymo laikotarpiu buvo statistiškai patikimai mažesnis trigubos LOPL terapijos grupeje FF/U/V, lyginant su dvigubo medikamentinio gydymo grupemis $(\mathrm{FF} / \mathrm{V}$, $\mathrm{U} / \mathrm{V})$. Pacientams, gydytiems FF/U/V, nustatytas vidutinio sunkumo ir sunkių LOPL paūmejjimų dažnis buvo 0,91 paūmejjimo pacientui per metus lyginant su FF/V grupès pacientais, kurių paūmèjimų dažnis siekė 1,07 paūmèjimo per metus (15 proc. skirtumas; dažnio santykis (DS) 0,85 (95 proc. PI, $0,80-0,90)$; $\mathrm{p}<0,001$ ) ir U/V grupès pacientais, kurių paūmejjimų dažnis siekè 1,21 paūmèjimo per metus (25 proc. skirtumas; DS 0,75 (95 proc. PI 0,70-0,81); $\mathrm{p}<0,001$ ) (2 pav. A). Atliekant duomenų iki pirmo LOPL paūmèjimo analizę, nustatyta, jog pacientų, kurių gydymui skirta triguba LOPL terapija FF/U/V, vidutinio sunkumo arba sunkaus paūmèjimo rizika buvo statistiškai patikimai mažesnè lyginant su FF/V grupe (rizikos santykis (RS) 0,85; 95 proc. PI, $0,80-0,91 ; 15$ proc. skirtumas; $\mathrm{p}<0,001)$ bei $\mathrm{U} / \mathrm{V}$ grupe (RS 0,84 (95 proc. PI, 0,78-0,91; 16 proc. skirtumas; $\mathrm{p}<0,001)$ (2 pav. B). Metinis vidutinio sunkumo ir sunkiu LOPL paūmèjimų dažnis taip pat buvo mažesnis trigubos terapijos grupeje (FF/U/V) lyginant su dvigubos terapijos grupèmis. Pastebėta, jog mažesnis metinių paūmejjimų dažnis nustatytas pacientams, kurių eozinofilų skaičius buvo $\geq 150$ ląstelių/ $\mu$ l. Metinis sunkių paūmèjimų dažnis buvo statistiškai reikšmingai mažesnis trigubos terapijos grupejje, lyginant su U/V grupe, tačiau statistiškai reikšmingo skirtumo tarp trigubos terapijos ir FF/V grupès nenustatyta. Metinis sunkių paūmèjimų dažnis trigubos terapijos grupeje buvo 0,13 paūmèjimo, FF/V grupeje 0,15 paūmejjimo (DS 0,87; 95 proc. PI 0,76-1,01; 13 proc. skirtumas; $\mathrm{p}=0,06)$ ir 0,19 paūmejjimo U/V grupeje (DS $0,66$; 95 proc. PI $0,56-0,78 ; 34$ proc. skirtumas; $\mathrm{p}<0,001)$.

I statistinę analizę ịtraukus ir lengvus LOPL paūmèjimus (kuomet papildomai gydymui skirtas tik trumpo veikimo $\beta_{2}$-agonistas), rezultatai buvo panašūs. Lengvų, vidutinio sunkumo arba sunkių paūmèjimų dažnis buvo 1,05 paūmejjimo per metus trigubos terapijos grupejje, 1,25 paūmèjimo - FF/V grupèje ir 1,4 paūmèjimo - U/V grupejje. Paūmèjimų dažnis buvo 16 proc. mažesnis trigubos terapijos grupeje, lyginant su FF/V grupe (DS 0,$84 ; 95$ proc. PI $0,79-0,89 ; \mathrm{p}<0,001$ ) ir 25 proc. mažesnis trigubos terapijos grupeje, lyginant su U/V grupe (DS 0,$75 ; 95$ proc. PI $0,70-0,81 ; \mathrm{p}<0,001$ ).

Vertinant spirometrijos duomenis, vidutinis $\mathrm{FEV}_{1}$ pokytis, lyginant su pradinio vizito vertemis, buvo žymiai didesnis trigubos terapijos grupeje: lyginant $\mathrm{FF} / \mathrm{U} / \mathrm{V}$ ir $\mathrm{FF} / \mathrm{V}$ grupes - $97 \mathrm{ml}$ (95 proc. PI 85-109; $\mathrm{p}<0,001)$, lyginant $\mathrm{FF} / \mathrm{U} / \mathrm{V}$ ir U/V grupes $-54 \mathrm{ml}(95$ proc. PI 39-69; $\mathrm{p}<0,001$ ) (2 lentelè). Teigiamas trigubos terapijos medikamentinis poveikis atsispindejo ir tiriamiesiems pildant Šv. Jurgio kvėpavimo klausimyną: didesnis vidutinis bendro balo pokytis nuo pradinio, kaip ir didesnis tiriamųjų skaičius, kuriems bendras balų skaičius sumažèjo bent 4 , nustatyti FF/U/V grupèje, lyginant su FF/V ir U/V grupe $(\mathrm{p}<0,001)$ (2 lentelè). Laikino dusulio indekso (angl. Transition Dyspnea Index, TDI), balo padidejimas $\geq 1$ balu, taip pat buvo didesnis trigubos terapijos grupeje ir siekè 36 proc., tuo tarpu FF/V grupejje - 29 proc., U/V grupejje - 30 proc. Teigiamo poveikio ŠS trigubos terapijos grupejje, lyginant su FF/V grupe, buvo 1,36 (95 proc. PI 1,19-1,55; $\mathrm{p}<0,001)$ ir 1,33 trigubos terapijos grupę lyginant su U/V grupe (95 proc. PI 1,13-1,57; $\mathrm{p}<0,001$ ).

Saugumo profilis ir užfiksuoti nepageidaujami reiškiniai buvo tiek LOPL gydant trijų, tiek dviejų vaistų deriniais. Sunkūs nepageidaujami reiškiniai užfiksuoti 22 proc. pacientų, vartojusių trigubą terapiją, 21 proc. tiriamujų, gydytų FF/V, 23 proc. asmenų, gydymui kasdien ịkėpusiems U/V. Pneumonija tiriamųju grupèse nustatyta atitinkamai - 184 (4 proc.), 152 (4 proc.) ir 54 (3 proc.) pacientams. Didesnis pneumonijų skaičius
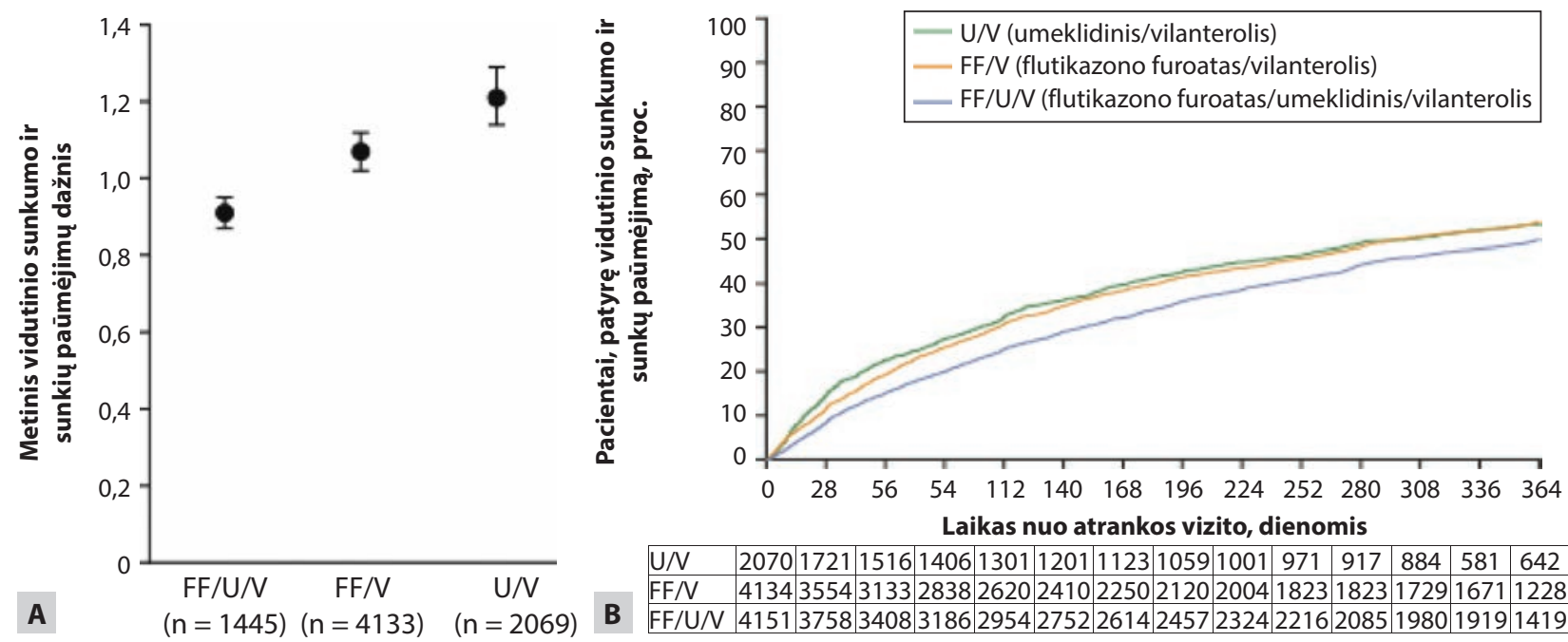

\begin{tabular}{|l|l|l|l|l|l|l|l|l|l|l|l|l|l|l|}
\hline U/V & 2070 & 1721 & 1516 & 1406 & 1301 & 1201 & 1123 & 1059 & 1001 & 971 & 917 & 884 & 581 & 642 \\
\hline
\end{tabular}

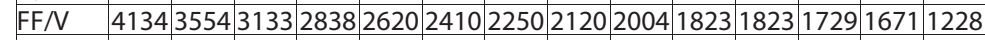
B $\mathrm{FF/U/V}$ 4151|3758|3408|3186|2954|2752|2614|2457|2324|2216|2085|1980|1919|1419

2 pav. Vidutinio sunkumo ir sunkių LOPL paūmèjimų dažnis: A - apskaičiuotas dažnis; B - laiko iki pirmo ịvykio analizè (analizè atlikta numatytų gydyti tiriamuoju vaistiniu preparatu populiacijoje) 
2 lentelè. $\mathrm{FEV}_{1}$ ir Šv. Jurgio kvèpavimo klausimyno bendrojo balo duomenys. Analizė atlikta numatytų gydyti tiriamuoju vaistiniu preparatu populiacijose

\begin{tabular}{|c|c|c|c|}
\hline Baigtys & $\begin{array}{l}\text { Triguba terapija } \\
\text { FF/U/V }(n=4151)\end{array}$ & $\begin{array}{l}\text { Dviguba terapija } \\
\text { FF/V ( } n=4134)\end{array}$ & $\begin{array}{l}\text { Dviguba terapija } \\
\mathrm{U} / \mathrm{V}(\mathrm{n}=\mathbf{2 0 7 0})\end{array}$ \\
\hline \multicolumn{4}{|l|}{ FEV $_{1}$} \\
\hline Vertintų pacientų skaičius, $\mathrm{n}$ & 3366 & 3060 & 1490 \\
\hline Vidurkis 52-ą gydymo savaitę, ml (95 proc. PI) & $1274(1265-1282)$ & $1177(1168-1185)$ & $1220(1208-1232)$ \\
\hline Vidutinis pokytis nuo pradinio, $\mathrm{ml}$ (95 proc. $\mathrm{Pl}$ ) & $94(86-102)$ & $-3(-12-3)$ & $40(28-52)$ \\
\hline Skirtumas tarp trigubos ir dvigubos terapijų, ml (95 proc. PI) & - & $97(85-109)^{*}$ & $54(39-69)^{*}$ \\
\hline \multicolumn{4}{|l|}{ Šv. Jurgio kvèpavimo klausimyno bendras balas } \\
\hline Vertintų pacientų skaičius, $\mathrm{n}$ & 3318 & 3026 & 1470 \\
\hline Vidurkis 52-ą gydymo savaitę, ml (95 proc. PI) & $45,0(44,5-45,4)$ & $46,8(46,3-47,2)$ & $46,8(46,1-47,4)$ \\
\hline Vidutinis pokytis nuo pradinio, $\mathrm{ml}$ (95 proc. $\mathrm{Pl}$ ) & $-5,5(-5,9-(-5,0))$ & $-3,7(-4,2-(-3,2))$ & $-3,7(-4,4-(-3,0))$ \\
\hline Skirtumas tarp trigubos ir dvigubos terapijų, ml (95 proc. PI) & - & $-1,8(-2,4-(-1,1))^{*}$ & $-1,8(-2,6-(-1,0))^{*}$ \\
\hline $\begin{array}{l}\text { Atsakas, vertintas remiantis Šv. Jurgio kvèpavimo klausimyno } \\
\text { bendru balu 52-ą gydymo savaitę, n (proc.) }\end{array}$ & $1723(42)$ & $1390(34)$ & $696(34)$ \\
\hline $\begin{array}{l}\text { Šansu santykis, lyginant trigubą terapiją su dviguba terapija } \\
\text { ( } 95 \text { proc. } \mathrm{PI} \text { ) }\end{array}$ & - & $1,41(1,29-1,55)^{*}$ & $1,41(1,26-1,57)^{*}$ \\
\hline
\end{tabular}

* $p<0,001$. Nurodomi vidurkiai yra mažiausių kvadratų vidurkiai. Šv. Jurgio kvèpavimo klausimyno galimas bendras balų skaičius 0-100, mažesnis balas žymi geresnę su sveikata susijusią gyvenimo kokybę. Atsaku laikytas Šv. Jurgio kvèpavimo klausimyno bendro balų skaičiaus sumažejimas $\geq 4$ balais, lyginant su pradiniu. Santrumpos: $\mathrm{FEV}_{1}$ - forsuoto iškvèpimo tūrio per pirmają sekundę (angl. Forced Expiratory Volume in 1 Second); FF - flutikazono furoatas; PI pasikliautinasis intervalas; $\mathrm{U}$ - umeklidinis; $\mathrm{V}$ - vilanterolis.

ir didesnè rizika susirgti pneumonija nustatyta pacientams, gydymui vartojusiems iGK/IVMB/IVBA ir iGK/ IVBA, lyginant su IVMB/IVBA grupe. IMPACT tyrimo duomenimis, mirčiu skaičius nuo įvairių priežasčiuc buvo statistiškai patikimai mažesnis grupėse, kuriose viena iš gydymo sudedamųų dalių buvo iGK (triguba terapija FF/U/V arba dviguba terapija FF/V) nei grupejje be iGK (U/V). FF/U/V ir FF/V grupèse taip pat nustatytas mažesnis mirčių nuo širdies ir kraujagyslių sistemos bei kvépavimo takų patologijos skaičius, lyginant su U/V grupe. Mirčių, sąlygotų LOPL, skaičius taip pat buvo mažesnis iGK vartojusių asmenų grupèse (FF/U/V, FF/V) nei U/V grupeje. Vertinant tyrimo rezultatus, nenustatyta jokių naujų saugumo reikalavimų, skiriant trigubą terapiją LOPL gydymui FF/U/V [5].

\section{APIBENDRINIMAS}

Atliktų tyrimų duomenimis, esant vidutinio sunkumo $\left(\mathrm{FEV}_{1} 80-50\right.$ proc.) ir sunkiai LOPL $\left(\mathrm{FEV}_{1}<50\right.$ proc.) su išreikštais simptomais (CAT $\geq 10$ balų) bei pasikartojančiais paūmejjimas (esant vidutinio sunkumo LOPL - bent dviem vidutinio sunkumo arba sunkiems paūmèjimai, arba bent vienam sunkiam paūmèjimui per metus; esant sunkiai LOPL - bent vienam vidutinio sunkumo arba sunkiam paūmejjimas per metus), gydymas trijų vaistų deriniu - iGK/IVMB/IVBA (FF/U/V) viename inhaliatoriuje statistiškai patikimai sumažino vidutinio sunkumo ir sunkių paūmèjimų dažnị, lyginant su dviguba LOPL terapija iGK/IVBA arba IVMB/ IVBA. Taip pat pastebėtas su sveikata susijusios gyvenimo kokybės bei plaučių funkcijos pagerèjimas. Taigi, kruopščiai atrinktai pacientų grupei triguba terapija iGK/IVMB/IVBA (FF/U/V) viename inhaliatoriuje yra perspektyvus medikamentinis LOPL gydymas.

Publikaciją remia farmacijos bendrovè UAB „GSK Lietuva“ LT/RESP/0091/18 Parengimo data: 201809

\section{LITERATŪRA}

1. Danila E, Sakalauskas R, Zablockis R, Malakauskas K, Bagdonas A, Biekšienė K, ir kt. Lètinès obstrukcinės plaučių ligos diagnostika ir gydymas. Lietuvos pulmonologų sutarimas. Vilnius: Lietuvos pulmonologu draugija; 2015. p. 10-3.

2. Pocket guide to COPD diagnosis, management, and prevention: a guide for health care professionals. Global Initiative for Obstructive Lung Disease, 2017. Available from: http:// goldcopd.org/wp-content/uploads/2016/12/wms-GOLD2017-Pocket-Guide.pdf [accessed 0825 2018].

3. Singh D, Papi A, Corradi M, Pavlišová I, Montagna I, Francisco C, et al. Single inhaler triple therapy versus inhaled corticosteroid plus long-acting $\beta 2$ agonist therapy for chronic obstructive pulmonary disease (TRILOGY): a doubleblind, parallel group, randomised controlled trial. Lancet. 2016; 388(10048):963-73.

4. Lipson DA, Barnacle H, Birk R, Brealey N, Locantore N, Lomas DA, et al. FULFIL Trial: Once-Daily Triple Therapy for Patients with Chronic Obstructive Pulmonary Disease. Am J Respir Crit Care Med. 2017; 196(4):438-46.

5. Lipson DA, Barnhart F, Brealey N, Brooks J, Criner GJ Day NC, et al. Once-Daily Single-Inhaler Triple versus Dual Therapy in Patients with COPD. N Engl J Med. 2018; 378(18):1671-80. 